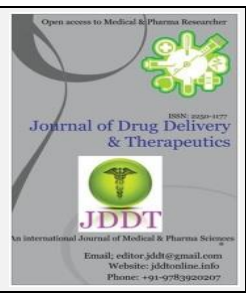

\title{
Phytochemistry and Hepatoprotective Activity of Chloroform Extract of NKC Ingredient in Santalum album Against D-Galactosamine Induced Hepatotoxicity in Rats
}

\author{
P. Kamalarajan ${ }^{1 *}$, Amalraj ${ }^{2}$, M. F.Valan ${ }^{3}$ \\ ${ }^{1}$ Research Scholar, Loyola Institute of Frontier Energy (LIFE), \\ 2 M.Sc Chemistry, Department of Chemistry, Loyola College, Chennai-600034, Tamil Nadu \\ ${ }^{3}$ Scientist, Loyola Institute of Frontier Energy (LIFE) \\ 1 \& 3Department of Chemistry, Loyola College, University of Madras, Chennai-600034, Tamil Nadu
}

\begin{abstract}
Objective: Nilavembu Kudineer Chooranam is the combination of nine plant materials. The nine components are Nilavempu (Andrographis paniculata), Vettiver (Vetiveria zizanioides), Vilamiccamver (plectranthus vettiveroides), Santanam (Santalum album), Peyputtal (Trichosanthes dioica), Koraikkilanku (Cyperus rotandus), Cukku (Zingeber officinale), Milaku (Piper nigrum), Parpatakam (Mollugo cerviana). All these plants are used conventionally in the treatment of fever, inflammation, arthralgia, arthritis, gastric ulcer, jaundice, and general weakness conditions.
\end{abstract}

Methods: About 500gm of dried fine powder of Santalum album were soaked in the extractor and macerated for 30 hrs with petroleum ether. On the $22^{\text {nd }} d a y$ after overnight fast the blood was collected from retro- orbital plexus. After the separation of serum from the blood assay of ALT, AST, ALP, $\gamma \mathrm{GT}$ and bilirubin were done using standard methods and enzyme assay tests.

Results: The preliminary phytochemical analysis of the Chloroform extract of Santalum album reveals the presence of alkaloid, flavonoid, phenol, coumarin, and tannin. The pretreatment of chloroform extract of Santalum album at a dose of $200 \mathrm{mg}$ and $400 \mathrm{mg} / \mathrm{kg}$ (group IV and V) appeared to significantly prevent the galactosamine toxicity as revealed by the hepatic cells which were preserved in cytoplasms.

Conclusion: Our findings demonstrated that chloroform extract of Santalum album at both doses possesses hepatoprotective and antioxidant activity, which is evidenced by lowered serum hepatic marker enzyme activities. Among the two dosages tested, $400 \mathrm{mg} / \mathrm{kg} / \mathrm{body} \mathrm{weight}$ showed more promising hepatoprotective and antioxidant activity, and is comparable to the standard drug Silymarin.

Keywords: Nilavembu Kudineer Chooranam, Chloroform extract of Santalum album, preliminary phytochemical analysis, Hepatoprotective activity, D-Galactosamine induced hepatotoxicity in rats.

Article Info: Received 14 July 2019; Review Completed 20 August 2019; Accepted 25 August 2019; Available online 30 Aug 2019

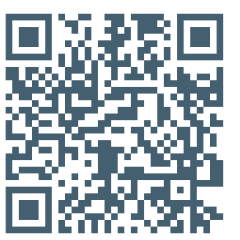

\section{Cite this article as:}

Kamalarajan P, Amalraj, Valan MF, Phytochemistry and Hepatoprotective Activity of Chloroform Extract of NKC Ingredient in Santalum album Against D-Galactosamine Induced Hepatotoxicity in Rats, Journal of Drug Delivery and Therapeutics. 2019; 9(4-A):176-182 http://dx.doi.org/10.22270/jddt.v9i4-A.3288

P. Kamalarajan, Research Scholar, Loyola Institute of Frontier Energy (LIFE), Loyola College, Chennai-600034, Tamil Nadu, India.

\section{INTRODUCTION:}

Siddha, Ayurveda, and Unani are the three medicinal systems of India. That is practiced from ancient time to this modern era. Among this Siddha which originated in the Southern part of India is the best conventional medicinal system in the world as it treats together with the body, mind and the soul. In this sera, it has been proved that Nilavembu Kudineer Chooranam (NKC) is bestowed with many therapeutic potentials and is considered as one of the best medicines in Siddha. It is regarded as a perfect health drink to cure many diseases. Nilavembu Kudineer Chooranam is the combination of nine plant materials. The nine components are Nilavempu (Andrographis paniculata), Vettiver (Vetiveria zizanioides), Vilamiccamver (plectranthus vettiveroides), Santanam (Santalum album), Peyputtal (Trichosanthes dioica), Koraikkilanku (Cyperus rotandus), Cukku (Zingeber officinale), Milaku (Piper nigrum), Parpatakam (Mollugo cerviana). Equal Proportion of the above nine ingredients are used in NKC ${ }^{1}$. All these plants are used conventionally in the treatment of fever, inflammation, arthralgia, arthritis, gastric ulcer, jaundice, and general 
weakness conditions 2-4. Among the nine components, the Santalum album plays a vital role contributing largely to the medicinal values of NKC. It is learned from the ancient Indian the plant has played Medicinal System that the plant Santalum album (L.) has played a significant role as it has been used as an astringent, antipyretic, blood purifier, disinfectant in bronchial and genitourinary tract infections, diuretic, expectorant, memory enhancer, and sedative, the tonic for heart, liver and stomach ${ }^{5}$. The present study aims at the evaluation of the hepatoprotective potential of Santalum album (stem) against paracetamol-induced hepatotoxicity. According to the literature of Siddha and Ayurveda NKC improves liver functions. The hepatoprotective activity of NKC warrants a scientific pharmacological study. The preliminary phytochemical analysis of the Chloroform extract of Santalum album reveals the presence of alkaloid, flavonoid, phenol, coumarin, and tannin. Hepatoprotective screening of Santalum album renders a better method for the evaluation of liver protecting the role of NKC. The model system of liver damage produced by D-galactosamine (GalN) is comparable with viral hepatitis in humans morphologically and functionally ${ }^{6}$. As a result, this model is now accepted as one of the most authentic test systems of liver damage in experimental animals. GalN has great liver specificity because the hepatocytes have high levels of galactokinase and galactose-1-P-uridylyltransferase.

Meanwhile, other organs are not affected 7-8. GalN causes liver cell injury, with spotty hepatocyte necrosis and prominent portal and parenchymal inflammation ${ }^{9}$. GalN also causes depletion of uridine diphosphate (UDP). GaIn converts uridine diphosphate (UDP) into UDP-sugar derivatives. Inhibition of RNA and protein synthesis by UDPsugar derivatives leads to deterioration of the cell membranes 10-11. Developing nations use medicinal plants for primary health care. The human body responds well when herbal drugs are administrated.

\section{MATERIALS \& METHODS:}

The whole plant of Santalum album was collected from authenticate herbal trader, Mylapore, Chennai, Tamilnadu, shade dried for a week in a shadow and blended to a coarse powder. Then a Taxonomist authenticated the plant sample. About 500gm of dried fine powder of Santalum album were soaked in the extractor and macerated for $30 \mathrm{hrs}$ with petroleum ether. There it is reflexed successfully with ethyl acetate, after that it is extracted with chloroform by continuous hot percolation method using soxhlet apparatus for $40 \mathrm{hrs}$ separately. The chloroform extract was filtered and concentrated in vacuum using rotary flask evaporator under reduced pressure. After concentration chloroform extract of Santalum album gave a brownish residue that was stored in an airtight container.

Animals In-house laboratory-bred six weeks old Wistar rats were selected for the study. Animals were maintained under the controlled temperature at $20 \pm 20{ }^{\circ} \mathrm{C}$ and relative humidity of $50-60 \%$ with an alternating $12 \mathrm{hr}$ light/ dark cycle. The animals were acclimatized for one week before the study and had free access to standard laboratory feed and water ad libitum.

\section{Study Design}

Rats of body weight $180-220$ g were selected. The total number of 30 rats was divided into five groups of 5 animals each.

Group I: Normal Control: The animals received distilled water $5 \mathrm{ml} / \mathrm{kg}$ b.w. p.o. for 21 days. Group II: Toxicant NGalactosamine Group: Also received distilled water $5 \mathrm{ml} / \mathrm{kg}$ b.w. p.o. for 21 days. A dose of D-Gal N in D.W. $400 \mathrm{mg} / \mathrm{kg}$ b.w was given i.p. after one hour of the vehicle ${ }^{12}$.

Group III: Standard Silymarin Group: The animals received silymarin $75 \mathrm{mg} / \mathrm{kg}$ b.w. p.o. was given for 21days. The animals received a single dose of D-Gal N in D.W 400 $\mathrm{mg} / \mathrm{kg}$ b.wi.p after 1 hour of std drug on the $21^{\text {st }}$ day.

Group IV Toxicant + Santalum album: $200 \mathrm{mg} / \mathrm{kg}$ was p.o. for 21 days. A dose of D-Gal N in D.W $400 \mathrm{mg} / \mathrm{kg}$ b.w. was given i.p. after 1 hour of the test drug.

Group V Toxicant + Santalum album: $400 \mathrm{mg} / \mathrm{kg}$ was p.o. for 21 days. The animals received a dose of D-GalN in D.W.400 mg / kg b.w.p.o after 1 hour of the test drug.

Biochemical Parameters: On the $22^{\text {nd }}$ day after overnight fast, the blood was collected from retro-orbital plexus. Before centrifugation at $2500 \mathrm{rpm}$ for ten minutes, blood was allowed to clot. After the separation of serum from the blood assay of alanine transaminase [ALT] 13, aspartate transaminase [AST] 14, alkaline phosphatase [ALP] 15, $\gamma$ glutamyl transferase $[\gamma \mathrm{GT}]{ }^{16}$ and bilirubin were done using standard methods and enzyme assay tests. Transasia Biomedicals Ltd Kit for ALT, AST, LDH and Accurex Biomedicals Ltd Kit for $\gamma$ GGT \& ALP. The enzyme assays were performed on a semi-autoanalyzer ERBA Chem.

Evaluation of Biochemical Parameters: The livers were dissected out immediately, washed with ice-cold saline and $10 \%$ homogenates in phosphate buffer solution $(\mathrm{pH} 7.4)$ were prepared. The following biochemical measurements were carried out in the liver tissues. Liver homogenate was used for the assay of MOA while some fraction of homogenates were centrifuged at $2500 \mathrm{rpm}$ for $10 \mathrm{~min}$ at 4 o $C$ using refrigerated centrifuge, and the supernatants were used for the assay of Superoxide dismutase (SOD), Catalase (CAT), Glutathione peroxidase (GPx) $17-19$ by standard methods using enzyme assay kits. The enzyme assays were performed on a semi-auto analyser ERBA Chem.

Histopathological Observation: The liver from each group was aseptically excused stored separately for analysis of oxidative stress-related biomarkers and in phosphate buffered formalin (10\%) for histopathological evaluation.

Statistical Analysis: The Statistical analysis was carried out by one-way analysis of variance (ANOVA) followed by NewmannKeul's multiple range tests. The values are represented as Mean \pm SEM. Probability value at $p<0.01$ was considered statistically significant.

Table: 1 Phytochemical analysis

Phytochemical Chloroform extract

\begin{tabular}{cc}
\hline Alkaloid & + \\
\hline Flavonoid & + \\
\hline carbohydrates & + \\
\hline Phenol & + \\
\hline Tannin & +
\end{tabular}


Table: 2 Effect of santalum album and silymarinpre-treatment on biochemical parameters of the rats intoxicated with d-galactosamine.

\begin{tabular}{|c|c|c|c|c|c|c|c|c|}
\hline $\begin{array}{c}\text { Group } \\
\text { No. }\end{array}$ & $\begin{array}{c}\text { TREATMENT } \\
\text { DOSE } \\
(\mathrm{mg} / \mathrm{Kg})\end{array}$ & $\begin{array}{c}\mathrm{AST} \\
(\mathrm{IU} / \mathrm{mL})\end{array}$ & $\begin{array}{c}\text { ALT } \\
(\mathrm{IU} / \mathrm{mL})\end{array}$ & $\begin{array}{c}\text { ALP } \\
(\mathrm{IU} / \mathrm{mL})\end{array}$ & $\begin{array}{c}\mathrm{TP} \\
(\mathrm{gm} / \mathrm{dl})\end{array}$ & $\begin{array}{c}\text { TB } \\
(\mathrm{mg} / \mathrm{dl})\end{array}$ & $\begin{array}{c}\text { GGTP } \\
(\mathrm{mg} / \mathrm{dl})\end{array}$ & $\begin{array}{c}\text { Total } \\
\text { Albumin(g/dl) }\end{array}$ \\
\hline I & $\begin{array}{l}\text { Normal control } \\
10 \mathrm{ml} / \mathrm{kg} \\
\text { normal saline }\end{array}$ & $\begin{array}{c}45.35 \pm \\
1.48\end{array}$ & $\begin{array}{l}30.20 \pm \\
1.02\end{array}$ & $\begin{array}{c}22.70 \pm \\
1.28\end{array}$ & $\begin{array}{c}5.16 \pm \\
0.32\end{array}$ & $\begin{array}{c}1.78 \pm \\
0.11\end{array}$ & $\begin{array}{c}96.84 \pm \\
2.64\end{array}$ & $\begin{array}{c}3.78 \pm \\
0.18\end{array}$ \\
\hline II & $\begin{array}{c}\text { Toxic control } \\
400 \mathrm{mg} / \mathrm{kg} \\
\text { D-galactosamine }\end{array}$ & $\begin{array}{c}* a \\
108.65 \pm \\
3.45\end{array}$ & $\begin{array}{c}* \mathrm{a} \\
93.40 \pm \\
3.32\end{array}$ & $\begin{array}{c}* a \\
141.20 \pm \\
5.25\end{array}$ & $\begin{array}{c}* a \\
3.18 \pm \\
0.14\end{array}$ & $\begin{array}{c}* \mathrm{a} \\
4.34 \pm \\
0.22\end{array}$ & $\begin{array}{c}*_{\mathrm{a}} \\
172.30 \pm \\
5.90\end{array}$ & $\begin{array}{c}* a \\
2.14 \pm \\
0.11\end{array}$ \\
\hline III & $\begin{array}{l}\text { Standard control } \\
\text { Silymarin } \\
75 \mathrm{mg} / \mathrm{kg}\end{array}$ & $\begin{array}{c}* b \\
59.15 \pm \\
1.68\end{array}$ & $\begin{array}{c}* \mathrm{~b} \\
41.22 \pm \\
2.04\end{array}$ & $\begin{array}{c}* \mathrm{~b} \\
52.35 \pm \\
2.38\end{array}$ & $\begin{array}{c}* \mathrm{~b} \\
3.94 \pm \\
0.21\end{array}$ & $\begin{array}{c}* \mathrm{~b} \\
2.74 \pm \\
0.18\end{array}$ & $\begin{array}{c}* \mathrm{~b} \\
122.24 \pm \\
3.14\end{array}$ & $\begin{array}{c}* \mathrm{~b} \\
2.88 \pm \\
0.14\end{array}$ \\
\hline IV & $\begin{array}{l}\text { Treatment control } \\
\text { Santalum album } \\
200 \mathrm{mg} / \mathrm{kg}\end{array}$ & $\begin{array}{c}* \mathrm{~b} \\
65.80 \pm \\
2.14\end{array}$ & $\begin{array}{c}{ }^{*} \mathrm{~b} \\
51.60 \pm \\
2.72\end{array}$ & $\begin{array}{c}* \mathrm{~b} \\
67.45 \pm \\
2.80\end{array}$ & $\begin{array}{c}* \mathrm{~b} \\
4.48 \pm \\
0.28\end{array}$ & $\begin{array}{c}* \mathrm{~b} \\
3.24 \pm \\
0.20\end{array}$ & $\begin{array}{c}\text { *b } \\
137.20 \pm \\
3.62\end{array}$ & $\begin{array}{c}* \mathrm{~b} \\
2.52 \pm \\
0.16\end{array}$ \\
\hline V & $\begin{array}{l}\text { Treatment control } \\
\text { Santalum album } \\
400 \mathrm{mg} / \mathrm{kg}\end{array}$ & $\begin{array}{c}* \mathrm{~b} \\
61.45 \pm \\
1.90\end{array}$ & $\begin{array}{c}* \mathrm{~b} \\
44.72 \pm \\
2.58\end{array}$ & $\begin{array}{c}* \mathrm{~b} \\
57.48 \pm \\
2.58\end{array}$ & $\begin{array}{c}* \mathrm{~b} \\
4.12 \pm \\
0.23\end{array}$ & $\begin{array}{c}* \mathrm{~b} \\
2.85 \pm \\
0.19\end{array}$ & $\begin{array}{l}* \mathrm{~b} \\
127.88 \pm \\
3.30\end{array}$ & $\begin{array}{c}* \mathrm{~b} \\
2.32 \pm \\
0.13\end{array}$ \\
\hline \multicolumn{9}{|c|}{$\begin{array}{l}\text { Values are expressed as Mean } \pm \text { SEM. } \\
\text { Values are found out by using one way ANOVA followed by Newmannkeul's multiple range tests. } \\
*^{*} \text { - - values are significantly different from Normal control at } \mathrm{P}<0.01 \text {. } \\
{ }^{*} \mathrm{~b}-\text { values are significantly different from Toxic control(G2) at } \mathrm{p}<0.01 \text {. }\end{array}$} \\
\hline
\end{tabular}

Table: 3 Effect Santalum album and Silymarin pre-treatment on biochemical liver parameter in d-galactosamine induced hepatotoxicity.

\begin{tabular}{|c|c|c|c|c|c|}
\hline $\begin{array}{l}\text { Group. } \\
\text { No. }\end{array}$ & $\begin{array}{c}\text { TREATMENT } \\
\text { DOSE } \\
(\mathrm{mg} / \mathrm{Kg})\end{array}$ & $\begin{array}{c}\text { SOD } \\
\text { (U/mg) } \\
\text { Protein }\end{array}$ & $\begin{array}{l}\text { CATALASE } \\
\text { (U/mg) } \\
\text { Protein }\end{array}$ & $\begin{array}{c}\text { GPX } \\
\text { (U/mg) } \\
\text { Protein }\end{array}$ & $\begin{array}{c}\text { MOA } \\
\text { (U/mg) } \\
\text { Protein }\end{array}$ \\
\hline I & $\begin{array}{l}\text { Normal control } \\
10 \mathrm{ml} / \mathrm{kg} \\
\text { Normal saline }\end{array}$ & $132.25 \pm 2.38$ & $290.35 \pm 4.38$ & $1.20 \pm 0.12$ & $3.95 \pm 0.24$ \\
\hline II & $\begin{array}{c}\text { Toxic control } \\
400 \mathrm{mg} / \mathrm{kg} \\
\text { D-galactosamine }\end{array}$ & $\begin{array}{c}* a \\
67.18 \pm 1.26\end{array}$ & $\begin{array}{c}* a \\
191.75 \pm 2.80\end{array}$ & $\begin{array}{c}* a \\
0.36 \pm 0.03\end{array}$ & $\begin{array}{c}* a \\
7.42 \pm 0.45\end{array}$ \\
\hline III & $\begin{array}{c}\text { Standard control } \\
\text { silymarin } \\
75 \mathrm{mg} / \mathrm{kg}\end{array}$ & $\begin{array}{c}* b \\
85.90 \pm 1.66\end{array}$ & $\begin{array}{c}{ }^{* b} \\
260.35 \pm 3.88\end{array}$ & $\begin{array}{c}{ }^{*} \mathrm{~b} \\
0.89 \pm 0.07\end{array}$ & $\begin{array}{c}{ }^{*} \mathrm{~b} \\
4.55 \pm 0.32\end{array}$ \\
\hline IV & $\begin{array}{c}\text { Treatment control } \\
200 \mathrm{mg} / \mathrm{kg} \\
\text { Santalum album }\end{array}$ & $\begin{array}{c}{ }^{* b} \\
96.15^{2} \pm 1.92\end{array}$ & $\begin{array}{c}{ }^{* b} \\
234.20 \pm 3.48\end{array}$ & $\begin{array}{c}* \mathrm{~b} \\
0.56 \pm 0.05\end{array}$ & $\begin{array}{c}{ }^{*} \mathrm{~b} \\
5.26 \pm 0.40\end{array}$ \\
\hline V & $\begin{array}{c}\text { Treatment control } \\
400 \mathrm{mg} / \mathrm{kg} \\
\text { Santalum album }\end{array}$ & $\begin{array}{c}* \mathrm{~b} \\
90.54 \pm 1.72\end{array}$ & $\begin{array}{c}* b \\
243.76 \pm 3.66\end{array}$ & $\begin{array}{c}{ }^{* b} \\
0.72 \pm 0.08\end{array}$ & $\begin{array}{c}{ }^{*} \mathrm{~b} \\
4.82 \pm 0.35\end{array}$ \\
\hline
\end{tabular}

$>$ Values are expressed as Mean \pm SEM.

$>$ Values are finding out by using one way ANOVA followed by Newmannkeul's multiple range tests.

$>*_{\mathrm{a}}-$ values are significantly different from Normal control at $\mathrm{P}<0.01$.

$>{ }^{*} \mathrm{~b}$ - values are significantly different from Toxic control(G2) at $\mathrm{p}<0.01$. 
Table: 4 Effect of santalum album on the levels of non enzymatic antioxidants in the liver tissue of d-galactosamine hepatotoxic and control rats

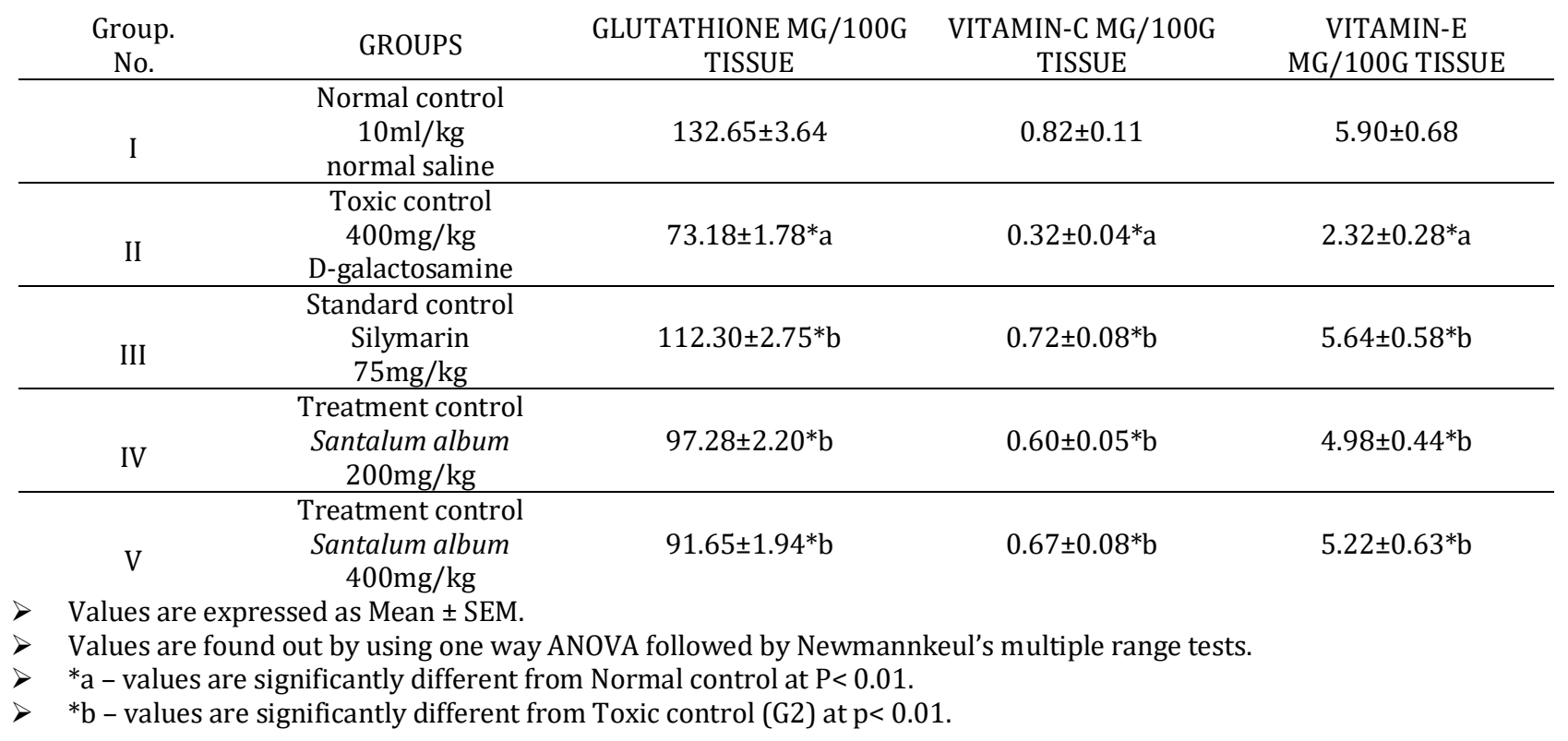

\section{RESULT:}

\section{Phytochemical screening}

The extract of Nilavembu Kudineer Chooranam was subjected to qualitative chemical examination for the presence of alkaloid, carbohydrates, flavanoids, tannin, and phenolic compound are reported in table -1 .

\section{Biochemical observations}

Significant increase in $(\mathrm{P}<0 \quad 0 \quad .01)$ Serum Aspartate Transaminase (AST) , Alanine Transaminase (ALT) , Alkaline phosphatase (ALP), Total bilirubin (TB) and Gammaglutamyltranspeptidase(GGTP) and significant decrease in $(\mathrm{P}<0.01)$ Total protein(TP) and Total albumin(TA) levels were observed in animals treated with galactosamine $400 \mathrm{mg} / \mathrm{kg}$ (Group II) as compared to normal control group(Group I).

Pretreatment with chloroform extract of Santalum album at a dose $200 \mathrm{mg}$ and $400 \mathrm{mg} / \mathrm{kg}$, orally for 21 days decreased the levels of above indices like AST, ALT, ALP, TB, GGTP and increased levels of TP and TA significantly( $\mathrm{P}<0.01)$ in group IV and V.

Silymarin pretreatment produced a significant decrease in $(\mathrm{P}<0.01)$ serum AST, ALT, ALP, TB, GGTP and the significant increase in TP and TA at $(\mathrm{P}<0.01)$ in group III.

\section{Biochemical observation in liver homogenate tissue}

In liver homogenate, there was a significant decrease in SOD, CAT and GPx levels and increase in LPO levels were observed in animals treated with galactosamine $400 \mathrm{mg} / \mathrm{kg}$ (group II) as compared to the normal control group (Group I).

Pretreatment with chloroform extract of Santalum album at a dose $200 \mathrm{mg}$ and $400 \mathrm{mg} / \mathrm{kg}$ orally for 21 days increase the levels of above indices like SOD, CAT and GPx levels and decrease levels of LPO significantly $(\mathrm{P}<0.01)$ in group IV and V.
Silymarin pretreatment produced a significant increase in $(\mathrm{P}<0.01)$ Liver homogenate enzyme such as SOD, CAT, GPx levels and decrease the levels of LPO significantly $(\mathrm{P}<0.01)$ in group III.

Table 4 shows the levels of non-enzymatic antioxidants such as reduced glutathione, Vitamin C and Vitamin $\mathrm{E}$ in the tissues (liver) of D-galactosamine hepatotoxic and control rats. There was a significant decrease in the levels of nonenzymatic antioxidant in D-galactosamine hepatotoxic rats. The chloroform extract of Santalum album at a dose $200 \mathrm{mg}$ and $400 \mathrm{mg} / \mathrm{kg}$ administered rats showed significantly increased levels of these non-enzymic antioxidants as compared with untreated hepatotoxic rats.

\section{Histopathological observations}

Normal liver architecture was observed in the histology of liver sections of normal control animals (Group I). Liver section of control healthy rats showed normal hepatic lobular architecture. The hepatocytes were within normal limits and arranged in thin plates.No fibrous tissue or lymphocytes deposition were observed. Ther was the presence of cytoplasm and prominent nucleus and nucleolus (Fig no: 1). The liver sections of galactosamine treated animals (Group II) showed hepatic cells with serum toxicity characterized by inflammatory cell collection, scattered inflammation across liver parenchyma, focal necrosis and swelling up of vascular endothelial cells (Fig no:2).

Silymarin (Group-III) exhibited protection from galactosamine-induced changes in the liver (Fig no: 3).

The pretreatment of chloroform extract of Santalum album at a dose of $200 \mathrm{mg}$ and $400 \mathrm{mg} / \mathrm{kg}$ (group IV and V) appeared to significantly prevent the galactosamine toxicity as revealed by the hepatic cells which were preserved in cytoplasms. The pretreatment of Chloroform extract of Santalum album also caused a marked decrease in inflammatory cells (Fig no:4 and 5). 


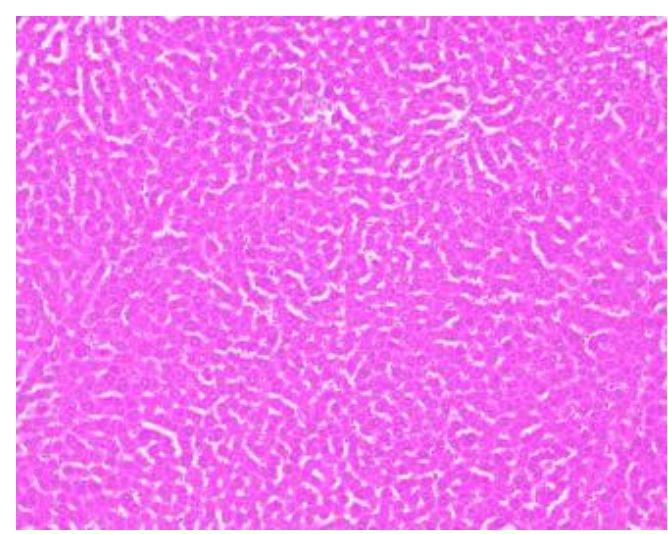

Figure No:1

Liver section of $\mathrm{GP}_{1}$ (Normal control)

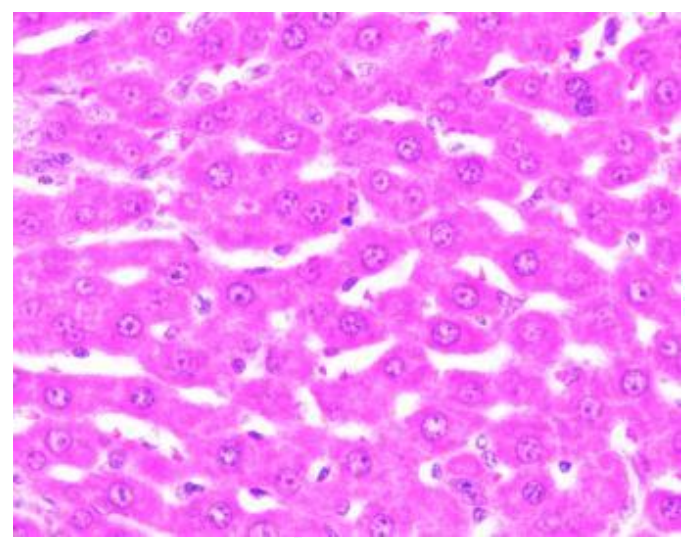

Figure No:2

Liver section of $\mathrm{GP}_{2}$ (toxic control)

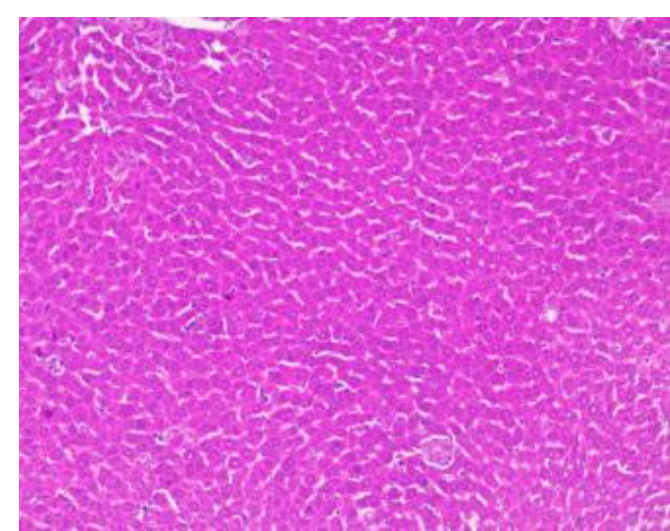

Figure No:3

Liver section of $\mathrm{GP}_{3}$ (standard control)

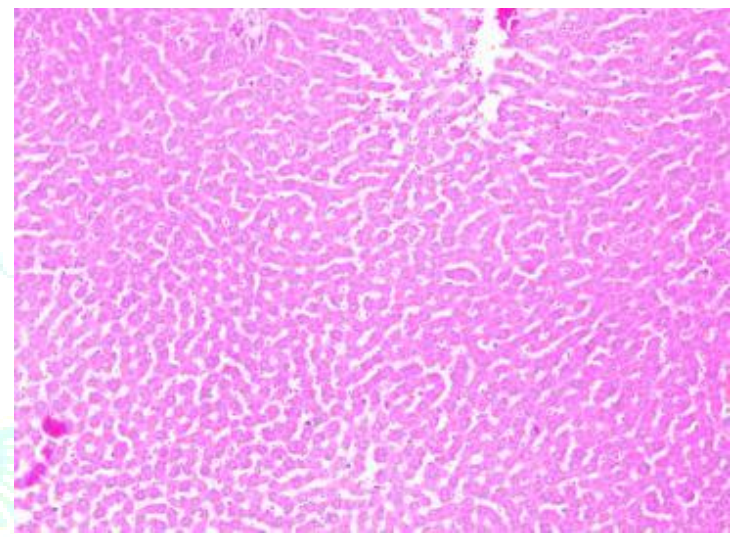

Figure No:4

Liver section of $\mathrm{GP}_{4}$ (santalum album $200 \mathrm{mg} / \mathrm{kg}$ )

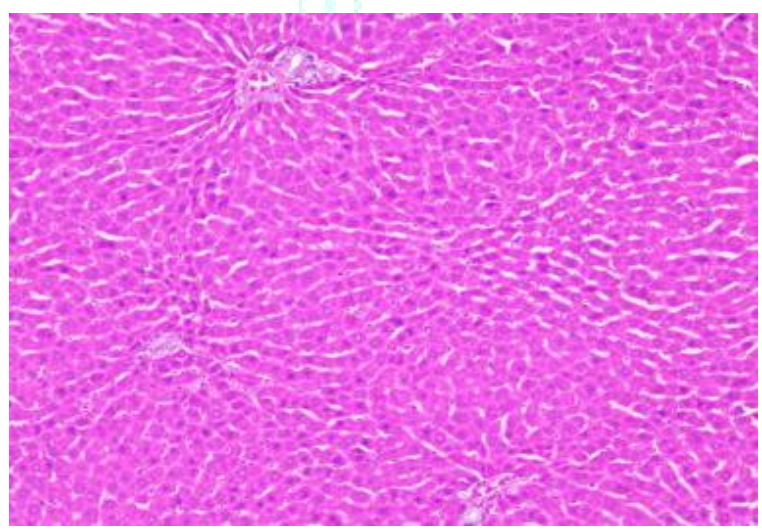

Figure No:5

Liver section of $\mathrm{GP}_{5}$ (santalum album $400 \mathrm{mg} / \mathrm{kg}$ )

\section{DISCUSSION:}

D-galactosamine is a hepatotoxicant. It injures the liver. Liver injury caused by D-galactosamine is similar to that of viral hepatitis.D-galactosamine disturbs the metabolism in the cells of the liver resulting in changes in the serum enzyme activities. The elevated serum enzymes indicate the cellular leakage and loss of functions of the hepatocyte 20 .

Enzymes such as aspartate aminotransferase, alanine aminotransferase, alkaline phosphatase, total bilirubin,and gamma-glutamyltranspeptidase are released into the blood veins when the liver cell plasma membrane is damaged. The in-vivo measurement of the above mentioned quantitative markers indicates the quantity and quality of hepatocellular damage.

In D-galactosamine induced toxicity, increased activities of aspartate aminotransferase, alanine aminotransferase, alkaline phosphatase, total bilirubin and gamma-glutamyl transpeptidase and decrease activities of complete protein and total albumin were observed in serum. The chloroform extract of Santalum album seems to preserve the structural integrity of the hepatocyte membrane resulting in the significant reduction in the activities of these enzymes. The $400 \mathrm{mg} / \mathrm{kg}$ dose had a better effect than the low dose of the 
chloroform extract of Santalum album (200mg/kg). The higher concentration might have resulted in the production of more byproducts that would have interfered with the activity. Treatment with chloroform extract of Santalum album significantly decreased these enzyme activities, indicating that chloroform extract of Santalum album has a hepatoprotective effect against a D-galactosamine-induced liver injury.

The formation of the highly reactive hydroxyl radical $(\mathrm{OH} \cdot)$ and lipid peroxidation are the harmful oxidative effects of Dgalactosamine. Consequently, the cell membrane is destructed 21 . The evidence clearly shows that the Dgalactosamine toxicity and lipid peroxidation damages the kidney 22. The presence of reduced antioxidants was observed in the kidney. The previous studies show that Dgalactosamine-induced rats significantly increased thiobarbituric acid reactive substances, lipid hydroperoxides and conjugated dienes in liver and kidney. In the present study, the observation indicates an increase in the levels of thiobarbituric acid reactive substances, lipid hydroperoxides and conjugated dienes in the tissues of D-galactosaminehepatotoxic rats. Increased lipid peroxidation in various tissues has long been known to cause functional degradation; thus, the deterioration of vital tissue leading to complications may be indirectly due to increased oxidative stress. Treatment with chloroform extract of Santalum album and silymarin showed a significant reduction which might be due to the antioxidant ability of these compounds and the consequent decrease in lipid peroxidation. The chloroform extract of Santalum album possesses antioxidative and free-radical scavenging effects.

Due to Oxidative stress, cell and tissue lack the antioxidant defense and the scavenging ability of reactive oxygen species. Lipid peroxidation, DNA damage, and the inactivation of many enzymes are other ill effects of oxidative stress 23 . The enzymatic antioxidant defense system is the natural protector against lipid peroxidation that includes superoxide dismutase, catalase and glutathione peroxidase. Reduced activities of these enzymes in the tissue of D-galactosamine- hepatotoxic rats were observed in our study. Superoxide dismutase protects against the superoxide radical (02--), which damages the membrane and its biological structure. Catalase primarily decomposes hydrogen peroxide to $\mathrm{H}_{2} \mathrm{O}$ at a much faster rate, sharing this function with glutathione peroxidase. Glutathione peroxidise removes lipid hydroperoxides. These enzymes remove oxygen radicals from tissues 24 .

Due to the increase in the levels of superoxide radicals and $\mathrm{H}_{2} \mathrm{O}_{2}$ the liver enzymes become inactive leading to death. The administration of chloroform extract of Santalum album significantly increased the activities of these enzymes.

The non-enzymic scavengers like glutathione, ascorbic acid, and $\alpha$-tocopherol, defend the residual free radicals escaping from decomposition by the antioxidant enzymes. These scavengers play the second line defense. Moreover, enzymic antioxidants are inactivated by the excessive levels of free radicals, and hence the presence of non-enzymic antioxidants is presumably essential for the removal of these radicals 25 .

Glutathione is a major non-protein thiol found in a living organism. It protects important thiol group from oxidation by combining with reactive oxygen species and electrophilic metabolites. It is perceived that the glutathione behaves as a substrate for enzyme like glutathione peroxidase. The lowered glutathione in D-galactosamine induced rats represent the increased utilization of glutathione as a result of oxidative stress. Perturbation in the redox status of glutathione not only impairs cellular defense against toxic compounds but also results in enhanced oxidative stress and oxidative injury 26. Free-radical scavengers protect cell membrane against poisonous agents.

$\alpha$-tocopherol (Vitamin E) and ascorbic acids (Vitamin C) are important free radical scavengers 27 . They prevent oxidative damage under all types of oxidative stress. Ascorbic acid possesses excellent power to trap lipid peroxy radical in the aqueous phase producing dehydro dehydroascorbate. The conversion of the dehydroascorbate into ascorbate is known as thiol cycle consisting of a GSSG/GSH couple. The active form of vitamin C ( ascorbic acid) is kept up in the cells by glutathione. Reduction in glutathione lowers ascorbic acid content. D-galactosamine hepatotoxic rats are found to have reduced glutathione $\alpha$-tocopherol and ascorbic acid levels due to an antioxidant defense against increased ROS

Ascorbic acid and $\alpha$-tocopherol decreased the hepatotoxic levels in the rats with liver injury, which received Dgalactosamine dosage. This study observes the increase in the levels of these antioxidants in chloroform extract of Santalum album and silymarin administered rats.

It is confirmed that chloroform extract of Santalum album inhibited lipid peroxidation. The antioxidant present in the extract accounts for the inhibition of lipid peroxidation. The anti-hepatotoxic activity of the chloroform extract counteracts the free radical-mediated tissue damage.

Antioxidants are flavonoid s. Flavonoids contain hydroxyl groups. Hydroxyl groups present in ring B of polyphenols are essential for the free radical scavenging mechanism of the anti-oxidants. The chloroform extract of Santalum album contains flavonoids. A high dose of $400 \mathrm{mg} / \mathrm{kg}$ body weight chloroform exatract of Santalum album improved the hepatoprotective and antioxidant activity in the rats having D-galactosamine-induced hepatitis.

\section{CONCLUSION:}

The findings demonstrated that chloroform extract of Santalum album at both doses possesses hepatoprotective and antioxidant activities. The lowered serum hepatic marker enzyme activities confirmed the antihepatotoxicity of plant extract. Among the two dosages tested, 400 $\mathrm{mg} / \mathrm{kg} /$ body weight showed more promising hepatoprotective and antioxidant activities and is comparable to the standard drug Silymarin. The observed significant hepatoprotective activity of Santalum album is a solid proof for the hepatoprotective activity of NKC.

\section{ACKNOWLEDGEMENT:}

We are grateful to all authors whose work we use in this review. The authors are thankful to K.M.College of Pharmacy, Madurai-625 107. Tamil Nadu., India for providing technical support in the course of this research work.

\section{CONFLICT OF INTEREST:}

The authors declare that they have no conflict of interest.

\section{ETHICAL APPROVAL:}

All applicable international, national, and/or institutional guidelines for the care and use of animals were followed. All procedures performed in studies involving animals were in accordance with the ethical standards of the institution or practice at which the studies were conducted. The research work was approved by the Institutional Animal Ethical Committee.

(IAEC//MU/48/PT/02/2016/PhD/KMCP/58/2019. 


\section{REFERENCES:}

1. Anbarasu K, Manisenthil Kumar KT, Ramachandran $\mathrm{S}^{*}$ 'Antipyretic, anti-inflammatory and analgesic properties of Nilavembu Kudineer Choornam: a classical preparation used in the treatment of chikungunya fever. Asian Pacific Journal of Tropical Medicine: 2011 pp.819-823.

2. Varier S. Indian Medicinal plants: a compendium of 500 species. 2nd ed. Vol. 1 and 2. Orient Longman Publication: Hyderabad; 1994.

3. Varier S. Indian Medicinal Plants: A compendium of 500 species. 2nd ed. Vol. 3 and 4. Orient

4. Varier S. Indian Medicinal Plants: A compendium of 500 species. 2nd ed. Vol. 5. Orient Longman Publication: Longman Publication: Hyderabad; 1995Hyderabad; 1996

5. Vengal Rao P Ashok Kumar CK, Ashwini G, Ambareesh Kumar $\mathrm{R}$ and Sangeetha S.Evaluation of Hepatoprotective Activity of Santallum Album (Stem) Against Paracetamol Induced Hepatotoxicity in Albino Wistar Rats . International Journal of Innovative Pharmaceutical Research.2014 pp 370-373

6. Keppler D, Lesch R, Reutter W, Decker K:Experimental hepatitis induced by $D$-galactosamine. Exp Mol Pathol 1968;9:279-290.

7. Maley F, Tarentino AL, McGarrahan JF, Del-Giacco R: The metabolism of $D$-galactosamine and $\mathrm{N}$-acetyl- $D$-galactosamine in rat liver. BiochemJ 1968;107:637-644.

8. Keppler D, Rudigier JFM, Bischoff E, DeckerK: The trapping of uridine phosphates by $D$-galactosamine, $D$-glucosamine and 2deoxy-Dgalactose.Eur J Biochem 1970;17:246-253.

9. Keppler D, Decker K: Studies on the mechanism of galactosamine hepatitis: Accumulation of galactosamine-1phosphate and its inhibition of UDP-glucose pyrophosporylase. Eur J Biochem 1969;10:219-225.

10. Decker K, Keppler D, Pausch J: The regulation pyrimidine nucleotide level and its role in experimental hepatitis. Adv Enzyme Regul 1973;11:205-230.

11. El-Mofty SK, Scrutton MC, Serroni A, Nicolini C, Farber JL: Early, reversible plasma membrane injury in galactosamineinduced liver cell death. Am J Pathol 1975;79:579-596.

12. Pushpavalli G, Kalaiarasi P, Veeramani C and Pugalendi KV: Effect of chrysin on hepatoprotective and antioxidant status in D-galactosamine-induced hepatitis in rats. Eur. J. Pharmcol 2010; 631: 36-41.

13. Jaishree $\mathrm{V}$ and Shrishailappa B: Antioxidant and hepatoprotective effect of swertiamarin from Enicostemma axillare against D-galactosamine induced acute liver damage in rats. Journal of Ethnopharmacology 2010; 130: 103-106.
14. Sandeep B, Balaji B, and Premkumar B: Hepatoprotective and antioxidant activity of Leucas aspera against D-galactosamine induced liver damage in rats. Pharmaceutical Biology 2012; 50(12): 1592-1595.

15. Persijn JP and VanderSlik W: A new method for the determination of gamma-glutamyl transferase in serum. J. Clin. Chem. Clin. Biochem 1976; 14(9): 421-7.

16. Lowry $\mathrm{OH}$, Rose brough, NJ, Far AL and Randall RJ: Protein measurement with the Folin phenol reagent. J. Biol. Chem 1951; 193(1): 265-75.

17. Wang Y, Li-Na G, Yuan-Lu C and Heng-Li J: Protective Effect of Danhong Injection on Acute Hepatic Failure Induced by Lipopolysaccharide and D-Galactosamine in Mice. EvidenceBased Complementary and Alternative Medicine 2014; 5: 1-8.

18. Peskin AV and Winterbourn CC: A microtiter plate assay for superoxide dismutase using a water-soluble tetrazolium salt (WST-1). Clin. Chim. Acta 2000; 293(1-2): 157-66.

19. Beers RFJ and Sizer IW: A spectrophotometric method for measuring the breakdown of hydrogen peroxide by catalase. J Biol Chem 1952; 195: 133-140.

20. Orie Y, Yoshiaki S and Kiharu I: Hepatoprotective effect of germanium-containing Spirulina in rats with Dgalactosamine- and lipopolysaccharide-induced hepatitis. British Journal of Nutrition 2014; 111: 135-140.

21. Barry $\mathrm{H}$ and Gutteridge JMC. In: Barry, H. (Ed.), Oxford Clarendon Press Free radicals in biology and medicine 1989; 254-255.

22. Barrera G: Oxidative stress and lipid peroxidation products in cancer progression and therapy. ISRN Oncol. 2012; 13: 72-89.

23. Shimaa IR, Shalaby MA, Nehal A and El-Banna HA: Hepatoprotective and Antioxidant Effects of Silybum marianum Plant in Rats. IJAVMS 2011; 5(6): 541-547.

24. Sundaram R and Murugesan G: Hepatoprotective and antioxidant activity of a mangrove plant Lumnitzera racemosa. Asian Pacific Journal of Tropical Biomedicine 2011; 348-352.

25. Wojacki JL, Samachowiec B, Gonet S, Juzwiak E and DM: Effect of buck wheat extract on free radical generation in rabbits administered high fat diet. Phytother. Res 1995; 19: 323-326.

26. Jayachandran M, Lalithapriya S and Selvam PC: Effect of ascorbic acid supplementation on tissue ascorbic acid and nucleic acid content of young and aged rats. J. Clin. Biochem. Nutr 1995; 19: 131-136.

27. Ganie SA, Aahmad B, Masood ZA and Zargar MA: Hepatoprotective and Antioxidant Activity of Rhizome of Podophyllum hexandrum against Carbon Tetra Chloride Induced Hepatotoxicity in Rats. Bio medical and Environmental sciences 2013; 26(30): 209-221. 